\title{
特集：社交不安症
}

〈総 説〉

\section{社交不安症の疫学 一その概念の変遷と歴史一}

\author{
音羽健司 $^{1}$ 森田正哉 $^{2}$
}

${ }^{1}$ 帝京平成大学大学院臨床心理学研究科

${ }^{2}$ 東京大学医学部附属病院精神神経科

\begin{abstract}
要約
社交不安症（SAD）は社交場面や対人面において恐れや不安を抱き，それを回避することで日常生 活に支障を生じる疾患である。DSM-III 以降，欧米では多くの疫学研究が行われるようになり，有病 率の高さが注目された。DSM-IVでは社会恐怖の診断名に「社会不安障害」が併記され, 恐怖症から 不安障害へと名称・概念の変遷に至った。また, 他の精神疾患の併存率の高さも指摘されており, 特 にうつ病や自殺のリスクに注意が必要である。DSM-5で初めて, SADはこれまでの自己主体性の不 安だけでなく他者主体性の症状が盛り込まれ, わが国固有の対人恐怖症とほぼ同一の疾患概念として 捉えられるようになった。本邦ではいまだ見逃されている」精神疾患であり, 診断と治療が依然十 分には行き届いているとはいえない。わが国特有の文化的背景も考慮に入れつつ, 患者に最適な治療 が届くようにSADを見落とさない努力を医療者側が行う必要がある。

キーワード：DSM-5, 社交不安症, 対人恐怖症, 併存症, 有病率
\end{abstract}

\section{【はじめに】}

社交不安症 (Social Anxiety Disorder; SAD) は, スピーチや発表などの社交場面や対人面に おいて, 苦痛を感じるほどの恐れや不安を抱 き，それを極力回避しようとすることで日常生 活に支障を生じる疾患である。人前に出て発表 する際に恥ずかしくなり緊張するということ は, 誰にでも起こりうるものでありSADの本 態ではない。その状況に直面する前に「恥ずか しい思いをするのではないか」,「ばかにされる のではないか」と極度の不安を抱き, さらにそ の不安を何とか消そうと状況を回避しょうとす ることで，かえって不安が増大することこそが 疾患の本態ともいえる。

欧米では近年になりようやく認識されるよう になった病態像だが, 日本においては以前から 知られていた。森田正馬は, 当時神経衰弱と一 括りにされていた病態のなかから, 対人場面に
おいて恐怖にとらわれることで生活に支障を来 たしている病態に対し「対人恐怖」と名づけ, 神経症の本態と精神療法についての研究を重 ね, 入院森田療法を完成させ, それまで治療法 のなかった対人恐怖の治療に先鞭をつけた（北 西・中村, 2005)。

森田のいう神経症を理解するうえで最も重要 なメカニズムは, 精神交互作用である。精神交 互作用とは, 不安や恐怖などの感覚に対して過 度に意識が集中することで，その感覚はより一 層鋭敏になり症状の発展・固着に至ることを指 す（森田，2014）。SADに照らし合わせるなら ば，人前で何かをすることに対する不安が発生 し，その不安を過度に意識することでますます 注意が集中してしまう。すると, 不安・恐怖へ の病感や身体感覚の異常が強く感じられ, 結果 としてそのことしか考えられない状態になる。 この悪循環の現象を指し, 森田は「とらわれ」 と呼んた（北西·中村, 2005)。 
では対人面に扮ける「不安」の正体とは一体 何だろうか。社会は，人と人との結びつきで構 成されている。自己以外の他者が存在するとい うことは, 社会生活を営むうえで他者を意識せ ざるをえず，同時に他者の意識に自分がのぼっ ていることも考慮せざるをえないということで ある。その状況下に拈いて人は, 少なからず 「相手に良く思われたい」という願望を抱く。 この欲求が強ければ強いほど, うまくいかな かった場合を想定し，「相手に嫌われたらどう しょう」「変なふうに思われたらどうしよう」 と理想と現実のギャップに葛藤する。これこそ が社交不安の正体である。すなわち不安とは, 誰しもが大なり小なり抱く「あって当然のも の」といえるが，より良く生きたいという人間 本来の「生の欲求」が人一倍あるからこそ，か えって不安も大きくなるのだと考えられる。

SADは，そうした悪循環により不安が増大 し，日常生活に支障を来たす疾患である。近年 になり注目され始めたが，依然として診断と治 療が他の精神疾患ほど行き届いていない疾患で もある。本稿では, これまでのSADの疫学研 究の歴史, 有病率, 併存症, DSM-5での診断 基準の変更点などの概念の変遷を中心に記述し た。

\section{【疫学研究の歴史】}

近年になり注目されつつあるSADの疫学を 知るには，その歴史を振り返る必要がある。 $\mathrm{SAD}$ 概念は近代に入るまで認められていな かった。1960年代, アメリカ精神医学会によっ て出版され操作的診断として全世界で広く用い られている精神障害の診断と統計マニュアル

(Diagnostic and Statistical Manual of Mental Disorders) DSM-IIにおいては恐怖神経症 (phobic neurosis) の項目があるのみだった。 SAD としての歴史は, 1966 年に Marks \& Gelder（1966）によって報告されたことから始 まった。彼らは恐怖症の臨床的特徵をまとめ, それらを広場恐怖, 特定の恐怖症, 社会恐怖の
3タイプに分類し，恐怖症によって発症年齢や 性差が異なることを示した。SADの前身であ る社会恐怖（social phobia）について，「社会 との交流があるときに悩んだり回避する際に， じろじろみられたり評価されることへの過度の 恐怖」と定義された。1980年代に入りDSMIIIに改訂され，社会恐怖は恐怖症から独立し た項目として初めて記載された。診断基準が示 されたことをきっかけとして，欧米でも多くの 疫学研究が行われるようになった。DSM-IIIの 診断基準を使用して作成された面接法である Diagnostic Interview Schedule（DIS）を用いて 行われた大規模調査として, 米国国立精神衛生 研究所の Epidemiologic Catchment Area (ECA) 研究がある。米国の 5 力所の地域から抽出した 18 歳以上の約 2 万人を対象とし, 精神医学的診 断や社会経済的状況，精神保健サービスの概要 を調查した。このECA 研究の結果から, Schneier et al. (1992) がSADについて分析し たところ， 13,537 人のうち，2.4\%（361人）が $\mathrm{SAD}$ の診断を満たすことを報告した。同調査 においてSADの診断基準を満たしたうちの約 $70 \%$ が女性であった。また，SADの診断基準 を満たした群はそうでない群と比べ，若年，低 所得, 教育程度が低く, 独身, 別居状態, 離婚 状態の者が多かった。同じDISを用いた研究を ヨーロッパでも施行したところ米国同様の生涯 有病率が推定されたが（Wittchen et al., 1992）, アジア圈では台湾で $0.4 \%$, 韓国では $0.2-0.6 \%$ と欧米よりも低い值であった（Lee et al., 1990; Hwu et al., 1989)。

DSM-III-Rに改訂された際にWHO 統合国際 診断面接 (WHO Composite International Diagnostic Interview; CIDI）が作成され，DSMIII-R と ICD-10 両方の診断基準に準じて社会恐 怖の診断を行うことができるようになった。こ のCIDIを用いて行われた代表的調査として 1992年に米国で行われた National Comorbidity Survey（NCS）がある。CIDIでは恐怖を抱く 状況として，(1)公衆の前で話す，(2)小グループ 
で話す，(3)用がないのに人に話しかける，(4)外 出先でトイレを使う，(5)誰かが見ている前で字 を書く, (6)公衆の前で飲食をするという六つの 場面を設定した。NCSの調査では社会恐怖の 生涯有病率は $13.3 \%, 12$ 力月有病率は $7.9 \%$ と 高い值が報告された。また，同調査において社 会恐怖は大うつ病性障害, アルコール依存に次 ぎ3番目に多くみられる精神疾患であることが 判明した（Kessler et al., 1994）。

1985年，Liebowitzは社交恐怖について「無 視されてきた障害」と報告し，大きな反響を呼 んだ（Liebowitz et al., 1985）。1987年にリーボ ヴィッツ社交不安尺度 (Liebowitz social anxiety scale; LSAS）が開発され，評価の基準が定まっ た。これは24項目に及ぶ特定の状況において 生じる恐怖感やそれに対する回避行動の頻度に ついてモニタリングを行い，重症度を評価する もので, SAD診断の補助的検査として有効で ある (Heimberg et al., 1999)。LSASの日本語 版として朝倉ら（2002）により翻訳された LSAS-Jがあり，本邦に扮けるSAD評価として 用いられている。より簡便に使用可能な評価尺 度として Mini social phobia inventory (Mini SPIN) がある。(1)恥をかくことに対する恐怖のせいで 何かを避けたりする, (2)注目の中心にいること を避ける，(3)ばかだと思われることや恥をかく ことを何より恐れる，以上の三つの質問を行う ことで簡易診断でき， $89 \%$ の感度と $90 \%$ の特 異度をもつとされる (Connor et al., 2001)。

評価基準が明確になるにつれて盛んに研究が 行われるようになり，1994年，DSM-IVの登 場とともに大きな転換期を迎える。社会恐怖の 診断名に「社会不安障害」が併記されるように なり, 恐怖症から不安障害へと名称・概念の変 遷に至った。恐怖とは特定の刺激に対する生物 学的反応であり, 安全への退避の動機を起こす 役目を果たしている。病態を表す名称としては 恐怖のほうが合致しているかもしれないが, 特 定の対象に恐怖を感じることよりも社会におけ る幅広い活動状況に対して不安を抱き生活に支
障を来たすという病態に合わせる方針をとっ た。何よりも重要なことは，「社会に対する恐 怖」という名称のもたらすスティグマが根強 く，受診動機の低下も懸念されたためSAD（社 会不安障害）へと病名変更を行う流れが形成さ れた。日本では「社会不安障害」と表記されて いたが，2008年，日本精神神経学会によって， より実態に近い表現の「社交不安障害」へと変 更された。

疾患概念が浸透しつつあるなか，2000年に 再 び National Comorbidity Survey Replication （NCS-R）が行われた。これは World Mental Health Survey Initiative Version of the World Health Organization Composite International Diagnostic Interview（WMH-CIDI）を用いた 全米規模での対面調査で，18歳以上の 9,282 人 が対象となった。その結果，SADの生涯有病 率は $12.1 \%$ であった（Kessler et al., 2005）。こ れは全般不安症の $5.7 \%$, パニック症の $4.7 \%$, 心的外傷後ストレス障害 (posttraumatic stress disorder; PTSD）の $6.8 \%$, 強迫症の $1.6 \%$ と比 較しても顕著に高いことが示されており，改め て有病率の高い精神疾患であることが浮き彫り となった。不安を抱きやすい状況として，公衆 の前でスピーチを行うことが $21.2 \%$ ，会議で自 分の意見を言うことが $19.5 \%$ ，初対面の人と会 うことが $16.8 \%$ と特に多く，他者からの評価を 受けやすい場面を特に恐れることが明らかと なった。また, 生涯有病率における年齢層の比 較として, 18-29歳は13.6\%, 30-44 歳は $14.3 \%, 45-59$ 歳は $12.4 \%, 60$ 歳以上は $6.6 \%$ と 若年層に偏りがみられた。すなわち人前でス ピーチやプレゼンテーションを行う機会の多い 年代に多くみられるといえる。発症が若年であ ることを裏づける調査として，若者の精神障害 について実態調査を行った精神保健疫学調査 （NCS-A）がある（Merikangas et al., 2010）。米 国における13-18歳の10,123人を対象とし WHO-CIDIを用いた対面調査を行ったとこ ろ, SADの生涯有病率は $9.1 \%$ であった。内訳 
として 13-14 歳が 7.7\%, 15-16 歳が 9.7\%, 17-18歳が $10.1 \%$ であり, 年齢とともに有病率 の増加がみられた。性差の比較では, 男子が $7.0 \%$ ，女子が $11.2 \%$ と女性のほうで有意に割 合が高かった。これまでの調査と同様, 広場恐 怖症やパニック症, 全般不安症, PTSD どよ りも高い有病率が示された。

また，同調査を用いてSAD と内気 (shyness) の疫学的差異について調べた研究がある (Burstein et al., 2011)。6,483 人の親へのイン タビューを実施したところ, 自身の子を内気で

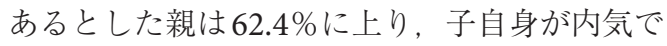
あると自認したのは $46.7 \%$ あ゙あた。それに対 し，DSM-IVのSADの規準を満たしたのは全 体の $8.6 \%$ あ゙あた。親に内気と思われている 群の $10.6 \%$, 内気と自認した群の $12.4 \%$ が $\mathrm{SAD}$ の診断基準を満たしたことになる。対照 的に, 親からみて内気とされなかった群の $5.5 \%$, 本人が内気と自覚していない群の $5.2 \%$ がSADの診断基準を満たした。同調査にて, 内気とした群よりもSADの診断基準に該当し た群のほうが生活上大きな役割障害を起こして おり, 気分障害, 行動障害, 物質誘発障害など の精神疾患を併存する割合の高いことが判明し た。特筆すべきは，SADの診断基準に該当す る者のうち, 治療薬であるパロキセチンの処方 がされていたのは $2.3 \%$ だけであったことであ る。このことから疾患の診断と適切な治療導入 がなされていない現状が浮き彫りにされ，著者 らは警笛を鳴らしている。以上の結果から,「恥 ずかしがり屋」,「内気」と性格の問題として片 付けられている者の中にもSADの診断基準を 満たし，日常生活に支障を来すほどの障害をも つ者が 1 割程度はいること,さらに本人の自覚 や周囲の評価だけではSADを否定することは できないということが分かった。発症年齢が他 の疾患よりも低いことは, 治療導入までの期間 が遅れることにつながり, 結果, 未治療のまま 進学や就職などのライフイベントをこなさなけ ればならず, 将来にわたっての自尊心の低下や
抑うつ状態の遷延が懸念される。

\section{【併存症について】}

SADは他の精神疾患を併存しやすいことで も知られている。NCSの調査結果から, 不安・ 恐怖症は互いに併存しやすいことが指摘され, 特にSADの診断基準を満たす群の 8 割が他の 精神疾患を併発していることが報告されている (Magee et al., 1996)。不安・恐怖症の併存は, 単体の不安・恐怖症よりも重篤に至るとされ る。1998年にドイツで実施された国民健康聞 き取り調査 (German National Health Interview and Examination Survey; GHS-MHS）では, 18-65 歳までの 4,773人を対象とし, WHO-CIDIを 改良したMunich Composite International Diagnostic Interview（M-CIDI）を用いてDSM-IV に準拠する形で精神疾患の評価を行った。その 結果, $\mathrm{SAD}$ の 12 力月有病率は $2.0 \%$ であり, 18-29歳の群が2.6\%と最も高い割合であった。 $\mathrm{SAD}$ の診断基準を満たした 83 人のうち $87.8 \%$ （73人）に及ぶ者が, 過去 12 力月の間に少なく とも一つ以上の精神疾患を呈していた。そのう ちの $20 \%$ が一つの精神疾患を, $20 \%$ ニ゙つの 精神疾患を併存し, $60 \%$ が三つ以上の精神疾 患を併存していた。多くの場合に拈いて, SAD が他の併存疾患より先行して出現することも示 された。特にSADに併存しやすい不安症の割 合として, 限局性恐怖症が $29.5 \%$, パニック症 が $25.6 \%$ ，全般不安症が22.2\%であった。また 不安症以外の精神疾患の併存率については, 気 分障害全体として $65.3 \%$, そのうち大うつ病で $50.5 \%$, 気分変調症で $38.1 \%$, 身体表現性障害 で31.3\%であった。その他, 物質関連障害とし

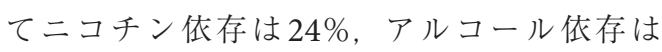
10.3\%の併存率であった（Fehm et al., 2008）。

対人場面における不安感や緊張を軽減するた めにアルコールや違法薬物に頼りすぎること で，薬物依存を発症するリスクが高まることも 懸念される。2001年, 米国でアルコール関 連障害全国疫学調査 (National Epidemiologic 
Survey on Alcohol and Related Conditions; NESARC）が行われた（Schneier et al., 2009）。 米国の人口調查に基づく年齢, 性別, 人種など の比率を考慮して選ばれた 18 歳以上の 43,093 人を対象とし対面調查を行ったところ, SAD の 12 力月有病率は $2.8 \%$, 生涯有病率は $5.0 \%$ であった。特にアルコール関連疾患と併存した $\mathrm{SAD}$ の生涯有病率は $2.4 \%$ であった。 SAD とア ルコール使用は強く関連するとはいえ, SAD に対しての早期介入によりこれらの併存を防ぐ ことができると考えられる。

SADの併存疾患として, 特にうつ病が懸念 される。Nepon et al. (2010) の報告において, SADにうつ病が併存した場合, 希死念虜が出 現しやすいことが示されている。うつ病は精神 疾患の中では代表的なものであり，己れまで自 殺対策を検討する場合にはうつ病に注目される ことが多かった。しかし Thibodeau et al. （2013）の報告によると, うつ病を併存してい ない不安症の多くも自殺に至ることが指摘され ている。2001年にヨーロッパ精神障害疫学研 究 (The European Study on the Epidemiology of Mental Disorders; ESEMED）として, 欧州 のベルギー, オランダ, スペイン, イタリア,
ドイッ, フランスの6カ国を対象に対面調査が 実施された（Bernal et al., 2007）。21,425人に 対しCIDIを用いて調査したところ, SADのう ち希死念慮を有した割合は $23.0 \%$ に上り, 自殺 企図に至った者は $7.60 \%$ であった。同研究にお ける比較対象として, 大うつ病の自殺企図率は 8.36\%であった。以上のことからうつ病を併存 した患者では自殺リスクは高まるが，SADの みでも自殺リスクは大うつ病とほぼ同様に高い ことが示唆された。また，前述のNCS-Rにお けるSADの希死念慮を呈する割合は 34.8\%, 自殺企図率は $14.3 \%$ であった (Cougle et al., 2009）。以上のことから，SADにおいても同様 に自殺リスクが高いことを医療従事者は認識し て臨床にあたるべきである。

\section{【日本の疫学研究】}

前述のように, 1960 年代以降, 日本では対 人恐怖症に関する研究が盛んに行われてきた。 多角的視点からの研究が数多く報告され, 笠原 （嘉）や山下らは対人恐怖を病状の多様性や臨 床的特徵に即して分類した（笠原， 2005）。一 方, 欧米では同様の病態についてほとんど認識 されて扮らず，対人恐怖症はアジア特有の疾患

Table 1 SAD と TKS の比較

\begin{tabular}{|c|c|c|}
\hline & SAD & TKS \\
\hline 精神症状 & 不安, 緊張, 回避行動 & 不安, 緊張, 回避行動, 希に妄想 \\
\hline 身体症状 & $\begin{array}{l}\text { 振戦, 選択的緘黙，めまい, 動悸, 赤面, 発汗, } \\
\text { 吐き気など }\end{array}$ & $\begin{array}{l}\text { 書㽿, 赤面, 動悸, 多汗症, 吃音, 自臭症な } \\
\text { ど }\end{array}$ \\
\hline 治療 & SSRI, CBT, 森田療法 & SSRI, CBT, 森田療法 \\
\hline 相違点 & 恥をかくことを恐れる（自己主体性） & $\begin{array}{l}\text { 相手を不快にさせてしまったのではないか, } \\
\text { と不安を感じる（他者主体性） }\end{array}$ \\
\hline DSM-IV & $\begin{array}{l}\text { 過剩な不安や緊張が誘発され, 身体症状を呈 } \\
\text { し, 対人場面を次第に避ける }\end{array}$ & $\begin{array}{l}\text { 日本の文化特有の疾患。外見, 表情, しぐさ } \\
\text { などによって, 他の人を不快にさせることを } \\
\text { 強く恐れ, 対人場面を次第に避ける }\end{array}$ \\
\hline DSM-5 & $\begin{array}{l}\text { 追記 : 不安症状をみせることで, 否定的な評 } \\
\text { 価を受けることになると恐れている } \\
\text { (すなわち, 恥をかいたり恥ずかしい思いをす } \\
\text { るだろう, 拒絶されたり, 他者の迷惑になる } \\
\text { だろう) }\end{array}$ & $\begin{array}{l}\text { 追記 : 社交不安症の基準を満たしており, 他 } \\
\text { の人たちを不快にさせているという恐怖と関 } \\
\text { 連している。アジア以外の状況でもみられる } \\
\text { かもしれない。 }\end{array}$ \\
\hline
\end{tabular}


であるとされ，文化依存症候群（文化結合症候 群) として「Taijin kyofusho」(TKS) がDSM-IV に登録された。TKSとSADはほほ同様の病態 だが, 一部ニュアンスの異なる部分がある (Table 1)。TKSは「他人と同席する場面に扮 いて，他人に軽䁾されたり不快感を与えたりす るのではないかという強い不安や緊張を抱くこ とにより，対人場面を避ける神経症」である。 SADが「不安を抱き, 自分が聎をかくのを恐 れる」ように，あくまで自己主体性が強くみら れるのに対して, TKSは「不安を抱き失敗し た場合に，他者を不快にさせてしまうのではな いか」と, 他者の感情を主体とする点で大きく 異なる。TKS と SADを同一の疾患とすべきか 否かという議論はみられたが, この点で大きな 違いがみられており，一線が引かれていた。

TKS は日本が中心となって研究を行ってき た疾患ではあったが,一方で日本における $\mathrm{SAD}$ の疫学研究はそれほど多くはない。代表 的かつ最も大規模な疫学調査として2002年に 行われた世界精神保健調査日本調査（World Mental Health Japan Survey) が挙げられる (Kawakami et al., 2005)。この調査では, 各地 域から抽出した 20 歳以上の 4,134 人に対し WHO-CIDIを用いて構造化面接を実施したと ころ, 日本に拈けるSADの12 カ月有病率は $0.8 \%$ であった。同調査では, 気分障害, 不安 障害, 物質関連障害のうち二つ以上併存した割 合は, 12 力月有病率で $2.2 \%$, 三つ以上で $0.9 \%$ となり, 同群では自殺行動のリスクが著しく増 加した。大学の学生健康診断時にリーボヴィッ ツ社交不安尺度を用いて予備調査を行った報告 では, 20,000人の対象のうち592人にあたる $2.8 \%$ がSDに該当した（西村ら，2007）。 さらに翌年, 大学全キャンパスでメンタルヘル ス調査を行ったところ，16,282人（回答率 $59.7 \%$ ）のうち $0.9 \%$ SAD とみなされた（西 村ら，2008)。Shindo et al. (2006）による日本 の大学病院精神科外来での初診患者調査では 5,000 人弱の初診に対して, SADの診断は
$1.04 \%$, 平均発症年齢は 18.6 歳と若年であっ た。日本での若年者での疫学調査デー夕は依然 そしく，また諸外国に比べ低い割合で示されて いる。

実際にアジアにおいて社会不安が低いかどう かを検討するには，欧米とアジアの社会性の成 熟の仕方に違いがあることを理解する必要があ る。Markus と Kitayamaは, 欧米でみられる相 互独立的自己観（independent self-construal）」 と東アジアの相互協調的自己観 (interdependent self-construal）という二つの異なる自己観の差 があると指摘する（Markus \& Kitayama, 1991）。 西洋人は, 自己を他者から独立した存在として 捉え, 自己効力感や自己決定を見いだす能力を 有することが社会における成熟を象徵する。対 照的に東アジアでは, 自己の価值を他者との関 係から見出そうとし，他者との協調や集団内で の調和を守ることこそ美德とされる。特に能力 を評価される場面として，自己を中心とした場 面よりも，他者や状況に調和できるかどうかが 重要となる。そのため, 個々に与えられた社会 の役割に準じようと努力するのである。アジア では, 自己能力よりも協調が第一であり, 自身 の主張は二の次となる。そうした文化に準じて 生活するアジア人は, より社交的な不安を感じ やすくなると考元れる。また，アジア圈のみ ならず，アジア系アメリカ人でもヨーロッパ系 アメリカ人に比べ社会不安レベルが高いことが 示されている (Norasakkunkit \& Kalick, 2002; Hong \& Woody, 2007)。これは, 文化的な違い を背景にもつアジア系アメリカ人は対人面で感 情を抑圧しやすく，ネガティブな感情を回避し たり抑圧したりすることでかえってその感情を 強めてしまう結果になり, 社交不安の発症に繋 がりやすく悪循環に陷りやすいと考えられる。

以上のように，アジア人の社交不安レベルは 他地域・他人種より高いと推測されるが，にも かかわらずSAD有病率が著しく低いという矛 盾がみてとれる。2004年, Dennis (2004) は Nature誌に「アジアの憂冀」と題した発表を 
行った。アジアにおいて精神疾患は, 道德的な 脆さや育て方の失敗が原因であるとされ, 当人 とその家族にとって大きな恥と罪の意識に結び つけられていることを指摘し，それゆえに受診 率の低下を招いていることを指摘した。これに は前述した社会における優先順位の付け方が影 響していると思われるが，周囲の目を気にして 受診につながらないばかりでなく, 疫学調査に おいても取り繕う傾向にある可能性が挙げられ る。また, 調査の方法にも限界点がみられる。 前述した世界精神保健調査において, 米国の回 答率が70.9\%であったのに対し，日本での回答 率は $55.1 \%$ と顕著に低かった。恥をかくことを 何よりも恐れるSADの負因をもつ人であれば, 回答への参加を回避するのは容易に想像でき る。以上のことから，アジアにおける社交不安 症の調査では, 正当な評価がなされているとは いえず，潜在的な患者群が他国より多い可能性 が考えられる。同時にDennisは, 中国や日本 において若年の自殺率が高い点を指摘する。他 国に比べて気分障害の有病率が低いにもかかわ らず年間自殺者数が高いことを示し, 若者の自 殺のリスク要因として他の精神疾患の存在を忘

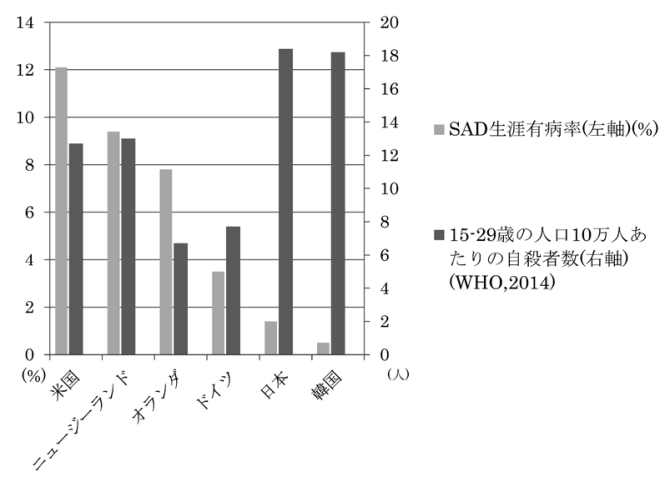

Figure $1 \mathrm{SAD}$ の国別有病率と若年層の人口 10 万人 あたりの自殺者数

注: 米国 (Kessler et al., 1994), ニュージーランド (Oakley Browne et al., 2006)，オランダ（Biji et al., 1998), ドイ ソ (Wittchen et al., 1998), 日 本 (Kawakami et al., 2005)，韓 国（Lee et al., 1990）の SAD 有病率と, 各国の自殺者数 (WHO, 2014)
れてはいけないという警鐘を鳴らしている (Figure 1)。特にSADは若年に好発する疾患で あり, 早発性うつ病のリスク因子であることを 考慮すると, 無視することはできないと考えら れる (Alpert et al., 1999; Parker et al., 1999)。

\section{【おわりに：DSM-IV からDSM-5へ】}

\section{3 年, DSM-5 (American Psychiatric} Association, 2013）が出版された。DSM-IVか らの変遷により, SADの重要な概念, 臨床的 含意も変更された。初発の年齢が 10 代と若年 であることが反映され，DSM-IVでは「18歳 未満の場合には，持続期間が6力月以上」で あったのに対し，DSM-5では，「すべての年齢 で6カ月以上」と年齢による基準が廃止された。 また，全般性かどうかの区別がなくなり，たと えばスピーチや動作などに限定される場合にお いて，パフォーマンス限局型SAD として区別 されるようになった。特筆すべきは, 診断概念 そのものの変化である。従来のSADの診断は 「自らが䎵をかくこと」が重要な構成要素の一 つではあったが, すべてのケースに当てはまる わけではなかった。DSM-5では「他者から否 定的な評価を受ける事を恐机る」が盛り込ま れ，より広い層を捉えられるようになった。さ らにDSM-5で初めて, 自己主体性の不安だけ でなく「他者の迷惑になるだろう」という他者 主体性の症状が盛り込まれた（Table 1)。これ は前述したわが国特有と考えられていた対人恐 怖症（TKS）の特徴でもある。これにより TKS と $\mathrm{SAD}$ 差異はほぼみられなくなり, SAD と TKS はほほ同一の疾患概念として捉えること が可能となったといえる。また, DSM-IIから これまでのSADの疾患概念の変遷についてま とめた (Table 2)。

DSM-5ではSAD（社交不安症）が代替的名 称から基幹的名称となった。これまでに示した ように, SADは受診率が低く治療導入に至り にくい疾患である。社会恐怖 (social phobia) の名称により，患者がネガティブな評価を与え 
Table 2 SAD の疾患概念の変遷

\begin{tabular}{|c|c|c|}
\hline 年代 & DSM & 概念 \\
\hline 1968 & DSM-II & $\begin{array}{l}\text { 社会恐怖の概念は明確にされていない。恐怖神経症の一つとして, 社交的場面に対しての } \\
\text { 過度の恐れが指摘されているのみである。 }\end{array}$ \\
\hline 1980 & DSM-III & $\begin{array}{l}\text { 社会恐怖の項目が初めて記載される。「他人の注視にさらされるような状況に対する恐れ」 } \\
\text { 「自分が恥をかいたり困惑したりするような行為を行うかもしれないという恐れ」が臨床的 } \\
\text { 特徴とされ, 「そうした状況や行為を避けようとし, それができない場合には強い不安と苦 } \\
\text { 痛を抱く」とされている。 }\end{array}$ \\
\hline 1994 & DSM-IV & $\begin{array}{l}\text { 名称では「社会恐怖」とともに「社会不安障害」が併記された。これまでの記述に加え, } \\
\text { 特定の対人状況において症状が出現するだけでなく, ほとんどの対人状況で症状が出現す } \\
\text { る全般型という亜型が追加された。 }\end{array}$ \\
\hline 2013 & DSM-5 & $\begin{array}{l}\text { 上記概念に加え，「他者から否定的な評価を受けることを恐れる（他者の迷惑になるだろ } \\
\text { う)」が追記された。 }\end{array}$ \\
\hline
\end{tabular}

られることを恐れて医療機関への受診につなが らないことが懸念されていた。これに対して Bruce et al. (2012) は「不安症」のほうが「恐 怖症」よりも治療を求める率が高くなることを 報告した。英語病名の変更に伴い2014年7月， 日本不安障害学会において, 日本語の疾患名を 不安障害から不安症に変更する旨が発表され， 学会名自体も日本不安症学会に変更された。不 安神経症を不安症と短縮することで馴染みやす くなり，また，精神障害という用語のイメージ を排除することで患者の誤解や不快感を減ら し，治療を受けやすくする工夫がなされたとい える。

一方，DSM-5では「文化の違いを考慮して 診断すべき」ともされている。「文化によって 社交的に不安があると捉えられる行動は, 別の 文化からすると適切とみなされるかもしれな い」という配慮からである。本人の自覚症状を 医師が評価する以上，文化の違いは念頭に置か れなければならないだろう。しかしアジア圏で SADの有病率が低いのは, 恥を恐れることが 礼節を重んじることになる文化だからというわ けではない。前述したように，アジア特有の背 景も考慮に入れ, SADである可能性を念頭に 置き, 見落とさない努力を医療者側が行う必要 があるだろう。SADは疫学的に有病率の高い 疾患であることを改めて認識し，治療の必要性
と治療による生活改善の可能性があることを広 く伝え続けることが肝要である。

\section{【文献】}

Alpert, J. E., Fava, M, Uebelackera, L. A., Nierenberga, A. A., Pavaa, J. A., Worthington, J. J., \& Rosenbauma, J. F. (1999). Patterns of Axis I comorbidity in early-onset versus late-onset major depressive disorder. Biological Psychiatry, 46, 202211.

American Psychiatric Association 日本精神神経学会 (監修) 高橋三郎·大野 裕 (監訳) (2014) DSM-5 精神疾患の診断・統計マニュアル 医学書 院. (American Psychiatric Association (2013) Diagnostic and Statistical Manual for Mental Disorders. (5th ed.). Washington DC: APA).

朝倉 聡·井上誠士郎・佐々木 史 - 佐々木幸哉・ 北川信樹·井上 猛・傳田健三・伊藤ますみ・松 原良次・小山 司 (2002). Liebowitz Social Anxiety Scale (LSAS) 日本語版の信頼性および妥当性の検 討精神医学, 44, 1077-1084.

Bernal, M., Haro, J. M., Bernert, S., Brughac, T., de Graafd, R., Bruffaertse, R., Lépinef, J. P., de Girolamog, G., Vilaguth, G., Gasqueti, I., Torresa, J. V., Kovessj, V., Heiderb, D., Neelemand, J., Kesslerk, R., \& Alonsoh, J. (2007). Risk factors for suicidality in Europe: Results from the ESEMED study. Journal of Affective Disorders, 101, 27-34.

Biji, R. V., Ravelli, A., \& van Zessen, G. (1998). Prevalence of psychiatric disorder in the general 
population: Results of the Netherlands Mental Health Survey and Incidence Study (NEMESIS). Social Psychiatry and Psychiatric Epidemiology, 33, 587-595.

Bruce, L. C., Heimberg, R. G., \& Coles, M. E. (2012). Social phobia and social anxiety disorder: Effect of disorder name on recommendation for treatment. The American Journal of Psychiatry, 169, 538.

Burstein, M., Ameli-Grillon, L., \& Merikangas, K. R. (2011). Shyness versus social phobia in US youth. Pediatrics, 128, 917-925.

Connor, K. M., Kobak, K. A., Churchill, L. E., Katzelnick, D., \& Davidson, J. R. (2001). Mini-SPIN: A brief screening assessment for generalized social anxiety disorder. Depression and Anxiety, 14, 137140.

Cougle, J. R., Keough, M. E., Riccardi, C. J., \& SachsEricsson, N. (2009). Anxiety disorders and suicidality in the National Comorbidity SurveyReplication. Journal of Psychiatric Research, 43, 825-829.

Dennis, C. (2004). Mental health: Asia's tigers get the blues. Nature, 429, 696-698.

Fehm, L., Beesdo, K., Jacobi, F., \& Fiedler, A. (2008). Social anxiety disorder above and below the diagnostic threshold: Prevalence, comorbidity and impairment in the general population. Social Psychiatry and Psychiatric Epidemiology, 43, 257-263.

Heimberg, R. G., Horner, K. J., Juster, H. R., Safren, S. A., Brown, E. J., Schneier, F. R., \& Liebowitz, M. R. (1999). Psychometric properties of the Liebowitz Social Anxiety Scale. Psychological Medicine, 29, 199-212.

Hong, J. J., \& Woody, S. R. (2007). Cultural mediators of self-reported social anxiety. Behaviour Research and Therapy, 45, 1779-1789.

Hwu, H. G., Yeh, E. K., \& Chang, L. Y. (1989). Prevalence of psychiatric disorders in Taiwan defined by the Chinese Diagnostic Interview Schedule. Acta Psychiatrica Scandinavica, 79, 136-147.

笠原敏彦 (2005). 対人恐怖と社交不安障害 (pp. 28-29). 金剛出版.

Kawakami, N., Takeshima, T., Ono, Y., Uda, H., Hata, Y., Nakane, Y., Nakane, H., Iwata, N., Furukawa, T. A., \& Kikkawa, T. (2005). Twelve-month prevalence, severity, and treatment of common mental disorders in communities in Japan: Prelim- inary finding from the World Mental Health Japan Survey 2002-2003. Psychiatry and Clinical Neurosciences, 59, 441-452.

Kessler, R. C., McGonagle, K. A., Zhao, S., Nelson, C. B., Hughes, M., Eshleman, S., Wittchen, H., \& Kendler, K. S. (1994). Lifetime and 12-month prevalence of DSM-III-R psychiatric disorders in the United States: Results from the National Comorbidity Survey. Archives of General Psychiatry, 51, 8-19.

Kessler, R. C., Berglund, P., Demler, O., Jin, R., Merikangas, K. R., \& Walters, E. E. (2005). Lifetime prevalence and age-of-onset distributions of DSMIV disorders in the National Comorbidity Survey Replication. Archives of General Psychiatry, 62, 593-602.

北西憲二・中村 敬 (2005). 森田療法 (心理療法プ リマーズ）（pp. 20-27）ミネルヴァ書房.

Lee, C. K., Kwak, Y. S., Yamamoto, J., Rhee, H., Kim, Y. S., Han, J. H., Choi, J. O., \& Lee, Y. H. (1990). Psychiatric epidemiology in Korea: Part I: Gender and age differences in Seoul. Journal of Nervous \& Mental Disease, 178.

Liebowitz, M. R., Gorman, J. M., Fyer, A. J., \& Klein, D. F. (1985). Social phobia; A review of a neglected anxiety disorder. Archives of General Psychiatry, 42, 729-736.

Magee, W. J., Eaton, W. W., Wittchen, H. U., McGonagle, K. A., \& Kessler, R. C. (1996). Agoraphobia, simple phobia, and social phobia in the National Comorbidity Survey. Archives of General Psychiatry, 53, 159-168.

Marks, I. M., \& Gelder, M. G. (1966). Different ages of onset in varieties of phobia. The American Journal of Psychiatry, 123, 218-221.

Markus, H. R., \& Kitayama, S. (1991). Culture and the self: Implications for cognition, emotion, and motivation. Psychological Review, 98, 224-253.

Merikangas, K. R., He, J., Burstein, M., Swanson, S. A., Avenevoli, S., Cui, L., Benjet, C., Georgiades, K., \& Swendsen, J. (2010). Lifetime prevalence of mental disorders in U.S. adolescents: Results from the National Comorbidity Survey ReplicationAdolescent Supplement (NCS-A). Journal of the American Academy of Child \& Adolescent Psychiatry, 49, 980-989.

森田正馬 (2014). 新版神経質の本態と療法 (p. 30) 


\section{白揚社出版}

Nepon, J., Belik, S. L., Bolton, J., \& Sareen, J. (2010). The relationship between anxiety disorders and suicide attempts: Findings from the national epidemiologic survey on alcohol and related conditions. Depression and Anxiety, 27, 791-798.

西村由貴 - 田中由紀子. 齋藤圭美 - 久根木康子 (2007). 学生のメンタルヘルス調査 2006一予備調 査の結果報告 慶應保健研究, 25, 59-66.

西村由貴 · 岩佐好恵 - 田中由紀子 - 藤井 香 ·高山 昌子（2008）大学生のメンタルヘルス全キャンパ 調査 2007 慶應保健研究, 26, 51-56.

Norasakkunkit, V., \& Kalick, S. M. (2002). Culture, ethnicity, and emotional distress measures. The role of self-construal and self-enhancement. Journal of Cross-Cultural Psychology, 33, 56-70.

Oakley Browne, M. A., Wells, J. E., Scott, K. M., \& Mcgee, M. A.; The New Zealand Mental Health Survey Research Team (2006). Lifetime prevalence and projected lifetime risk of DSM-IV disorders in Te Rau Hinengaro: The New Zealand Mental Health Survey. Australian and New Zealand Journal of Psychiatry, 40, 865-874.

Parker, G., Wilheim, K., Mitchell, P., Austin, M., Roussos, J., \& Gladstone, G. (1999). The influence of anxietry as a risk to early onset major depression. Journal of Affective Disorders, 52, 11-17.

Schneier, F. R., Johnson, J., Hornig, C. D., Liebowitz, M. R., \& Weissman, M. M. (1992). Social phobia. Comorbidity and morbidity in an epidemiologic sample. Archives of General Psychiatry, 49, 282288.
Schneier, F. R., Foose, T. E., Hasin, D. S., \& Heimberg, R. G. (2009). Social anxiety disorder and alcohol use disorder co-morbidity in the National Epidemiologic Survey on Alcohol and Related Conditions. Psychological Medicine, 40, 977-988.

Shindo, M., Shioiri, T., Kuwabara, H., Maruyama, M., Tamura, R., \& Someya, T. (2006). Clinical features and treatment outcome in Japanese patients with social anxiety disorder: Chart review study. Psychiatry and Clinical Neurosciences, 60, 410-416.

Thibodeau, M. A., Welch, P. G., Sareen, J., \& Asmundson, G. J. (2013). Anxiety disorders are independently associated with suicide ideation and attempts: Propensity score matching in two epidemiological samples. Depression and Anxiety, 30, 947-954.

Wittchen, H. U., Essau, C. A., von Zerssen, D., Krieg, J. C., \& Zaudig, M. (1992). Lifetime and six-month prevalence of mental disorders in the Munich Follow-Up Study. European Archives of Psychiatry and Clinical Neuroscience, 241, 247-258.

Wittchen, H. U., Nelson, C. B., \& Lachner, G. (1998). Prevalence of mental disorders and psychosocial impairments in adolescents and young adults. Psychological Medicine, 28, 109-126.

World Health Organization, 独立行政法人国立精神 · 神経医療研究センター精神保健研究所自殺予防総合 対策センター（訳）（2014）。自殺を予防する 世界の 優先課題. http://apps.who.int/iris/bitstream/10665/ $131056 / 5 / 9789241564779$ _.pn.pdf（2015 年 6 月 15 日 21 時 0 分). 


\title{
Epidemiology of Social Anxiety Disorder: Its History and Conceptual Changes
}

\author{
Takeshi OtowA $^{1}$ Masaya Morita $^{2}$ \\ ${ }^{1}$ Graduate School of Clinical Psychology, Teikyo Heisei University \\ Major of Professional Clinical Psychology \\ ${ }^{2}$ Department of Neuropsychiatry, The University of Tokyo Hospital
}

\begin{abstract}
Social anxiety disorder (SAD) is a mental disorder characterized by marked fear and anxiety in social or performance situations, and is associated with severe impairment in daily life functions due to the avoidance of such situations. Since the release of DSM-III, a large number of epidemiological studies have been conducted and have reported high morbidity in relation to this disorder. In DSM-IV, in addition to social phobia, "social anxiety disorder" was included in the classification of mental disorders, and this has been reflected in conceptual changes in diagnosis. Comorbidity with other psychiatric disorders has been reported and special attention is needed in cases of major depressive disorders and suicidal behaviors with especially high comorbidity rates. With DSM-5, for the first time, the definition of SAD included anxiety symptoms involving the viewpoint of others, such as "offending to others", as well as anxiety symptoms from a self-centered viewpoint. This means that SAD and "taijin kyofusho (fear of interpersonal relations)", a diagnosis particular to Japan, can be regarded as almost the same diagnostic concept. In Japan, SAD has been a "overlooked" disorder which is under-diagnosed and under-treated. Nevertheless, in consideration of Japan's unique cultural background, health care providers in Japan should be especially aware of SAD with the hope of achieving maximal improvement in these patients.
\end{abstract}

Key Words: DSM-5, social anxiety disorder, taijin kyofusho, comorbidity, prevalence 